\title{
Computing Education Competence in Higher Education: Challenges for Teachers
}

\author{
Cristina Hennig Manzuoli*, Yasbley Segovia Cifuentes \\ Centro de Tecnologías para la Academia, Universidad de La Sabana, Bogotá, Colombia \\ *Corresponding author: cristinahm@unisabana.edu.co
}

Received October 21, 2013; Revised October 31, 2013; Accepted November 18, 2013

\begin{abstract}
This paper presents positions and reflections about integrating Information and Communication Technologies (ICT's) to teaching practice in higher education and teaching-learning digital environments. The main issues discussed deal with the education a teacher must receive in order to achieve an ICT pedagogical integration in virtual or non-virtual environments, andto designlearning activities that contribute to knowledge building and application for problem solving froma transdisciplinaryapproach.
\end{abstract}

Keywords: computing education competence, ICT's integration, higher education, teachers' training

Cite This Article: Cristina Hennig Manzuoli, and Yasbley Segovia Cifuentes, "Computing Education Competence in Higher Education: Challenges for Teachers." American Journal of Educational Research 1, no. 9 (2013): 406-412. doi: 10.12691/education-1-9-9.

\section{Introduction}

Diverse studies find that the context in which teachers practice plays a key role when doing a pedagogical integration of ICT's. Teachers identify issues as technology supply, educational results achieved by students as well as teachers' skills for using technologies [1].

In general terms, teachers accept being trained on using technologies through courses, seminars, workshops, etc., but they perceive some failures in them such as reduced variety, short duration, big groups, and not enough computers for participants, among others.

Teachers acknowledge ICT's as tools for building knowledge mediated by collaborative activities that are relevant for participation in future society and guide towards an authentic problem solving as claimed by [2]. Collaborative work among teachers may contribute to the pedagogical ICT's use in the classroom. This work can be oriented in such a way that advanced teachers in innovation guide novice teachers. Students may also support the integration work of the teacher with minor tasks in the classroom, i.e. learning activities that require using ICT's. Teachers must use what was learnt about ICT's integration in courses for incorporating these practices inside the classroom and avoiding the risk of losingthe acquired knowledge.

\section{Developing Teachers' Competences for the Pedagogical Integration of ICT's}

Aimed at responding to the challenges arisen from incorporating information and communication technologies
(ICT's) in face-to-face education as well as in digital environments, the pedagogical concern of the teacher must be considered, sensing the usefulness of integrating ICT's to the curriculum as tools for facilitating student learning. This reflection will undoubtedly include the queries that guide the teacher's adequate use of ICT's and their goals inside the educational process. Thus, according to [3], the pedagogical reflections must allow the teacher to didactically incorporate ICT's, respecting the significance they may have in teaching learning processes. Inevitably, this integration must lead to reconsider the educational objectives, and to changes in the roles of teachers and students when facing this new challenge and the new organization entailed by incorporating ICT's.

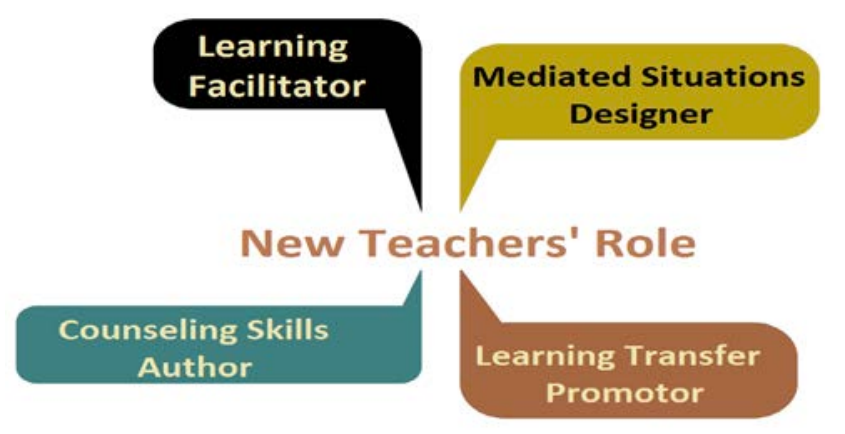

Figure 1. [3] Competence for online teaching: A special report. Educational Technological, Research and Development

The aforementioned claims impel teachers to develop technological competences that enable them to identify the possibilities of integrating ICT's as facilitators of the learning process and permanently monitor the incorporation proposed goals. The teacher's training must concur the development of other competences such as the methodological ones that, according to [3], will allow him 
to use the ICT's with a pedagogical sense and to have innovative didactic purposes that will undoubtedly lead to improving the students' learning process.

These proposals agree with approaches of organizations such as UNESCO who, through the ICT Competence Standards for Teachers [4], highlights the significance of developing this competence while simultaneously educating students in the appropriate ICT's use. Similarly, diverse investigations find teachers' capabilities in integrating ICT's; these capabilities may already be developed, (as the ones related to using the internet for data search), or they may be in development, (as the ones related to design multimedia material, teacher collaboration, use of virtual platforms and online tutoring).

Challenges for teachers are vast in this respect, as the existent resources can be used for mediating the learning process with the student. Its potential use is still unknown and limited to communication activities with the student, but not for learning activities that encourage a real knowledge building.

However, we cannot claim that knowledge building in face-to-face and digital educational environments only occurs due to the interaction of the process agents, i.e. teacher, students and materials. As [5] state, the effective use of ICT's integration will determine the students' learning results and the teaching processes transformation. Acquiring knowledge in face-to-face and digital environments is also determined by the teacher's vision of students' learning. Hence, a traditional teacher will use the ICT's for transmitting knowledge, while a more constructivist teacher will integrate them for collaborative work and inquiry processes of students.

The mentioned approaches about building knowledge in face-to-face and digital teaching environments have their advantages and their drawbacks. These will be discussed taking into account the approaches of authors such as [6], who claims that acquiring knowledge in these environments is affected by interaction processes, and highlighting the relevance of fostering communication among the agents of the interactive triangle teacherstudents-materials. This approach enhances the significance taken on by communicative processes in the online or mediated education processes. Nevertheless, it sets aside elements such as the ICT's integration usage contexts, i.e. the intentions of that integration and their effective uses given by teachers and students.

As previously mentioned, it is important to take into account the ICT's usage contexts, an interaction in which the teacher plays a key role in various areas[7]: the pedagogical one, related to developing an effective learning process; the social one, linked to a learning environment development that includes an emotional and affective climate where students feel learning is possible; the organizational and managerial one related with establishing an adequate educational design that includes encouraging those who are involved to be clear about their contributions; and, finally, the technical one, that encompasses actions focused towards assisting students to feel competent and comfortable with the resources and tools that shape the educational proposal.

The teacher's role in face-to-face and digital environments is then framed into supplying students with the demanded conditions for pursuing a learning process that privileges knowledge building. These conditions, or educational aids as named by [7], contribute to boosting students' learning; they are like mediators of the constructive activity of the student, and this mediation is performed by the teacher supported by ICT's and adjusting the joint activity.

Undoubtedly the mediation exercised by the teacher in face-to-face and digital environments are not the only ones involved in the student learning process. There are other educational aids linked to the knowledge building process done by the student, supported by the teacher, which together fosters learning possibilities. Educational aids related to the learning process that are mediated by the teacher are: communication, learning tasks, collaborative work, monitoring and assessment. The teacher can, to a lesser degree, participate in designing and organizing, as well as in research processes because they are preestablished by the programs' guidelines, and the teacher is limited to set in motion those aspects he is being asked for.

Table 1. Teacher's roles in the educational process mediated by technology

\begin{tabular}{|c|c|}
\hline \multicolumn{2}{|r|}{ TEACHERS’ ROLES IN TECHNOLOGICAL ENVIRONMENTS } \\
\hline Curricula design & Planning activities, choosing contents and resources, learning levels definition, complementary situations, etc. \\
\hline Information & Transmitting curricular content, response to students’ interests, data selection for students to access, etc. \\
\hline Education & Encouraging attitudes, skills, abilities, communication, interaction, feedback, etc. \\
\hline $\begin{array}{l}\text { Content \& material } \\
\text { elaboration }\end{array}$ & $\begin{array}{l}\text { Producing didactic \& technological material according to the necessities and characteristics of students; redesigning it } \\
\text { according to students' suggestions, etc. }\end{array}$ \\
\hline Orientation & Encouraging towards studying, supplying guidelines for using implied technologies, moderating interactions, etc. \\
\hline Evaluation & Permanent monitoring of the educational process of each student, his assessment, etc. \\
\hline
\end{tabular}

\section{Integrating ICT's with Learning Activities}

Teachers' training on ICT's integration must include, according to [1], training in methodology (didactics), taking into account the technical issues that must be present in this kind of education. Integrating ICT's with education implies a strong teacher education for having tools and resources that enable him to develop new competences which, in turn, facilitate the integration of technologies in a pedagogical way, in other words, to take into account the aims to reach in the learning process. These new competences impel the teacher to be in continuous training so as to be able to establish links between the didactic and pedagogical issues and the possibilities offered by technology nowadays. 
In this respect, [7], denotes the importance of including teaching and learning issues in teachers' training for a pedagogical ICT integration. Subsequently, it is vital for the teacher to know the possibilities of new learning scenarios provided by the ICT's. Then, ICT's are conceived as potential mediators in the teaching learning process in any education mode.

The teacher's new role implies being aware of the new time and space possibilities (virtual classrooms), being aware of the learning guide and facilitator agent he must be, and noticing the new possibilities of linking and supplying elements capable of boosting pupils' abilities.

In this way, the changes proposed by [8] are highlighted:

1. Communication: communicative tools, media; communication among students, with teacher and content is fostered. Cognitive processes are involved.
2. Methodological strategies: active methodologies.

3. Informative function: teacher as guide.

4. Labor \& professional environment: preparedness for job context.

From this perspective, the new learning conception, in which the student is the center of the process, implies that the teacher has to know the students' prior knowledge and offers him the needed aid for reaching learning (by means of activities that encourage thinking skills and set them in motion in the diverse developing contexts of the student).He also has to know the interaction possibilities this knowledge may have for solving different problems that are identified through an interdisciplinary diagnose. Besides, the teacher has to know the result of combining this knowledge for boosting problem solving possibilities; authors such as [9] highlight all of these aspects.

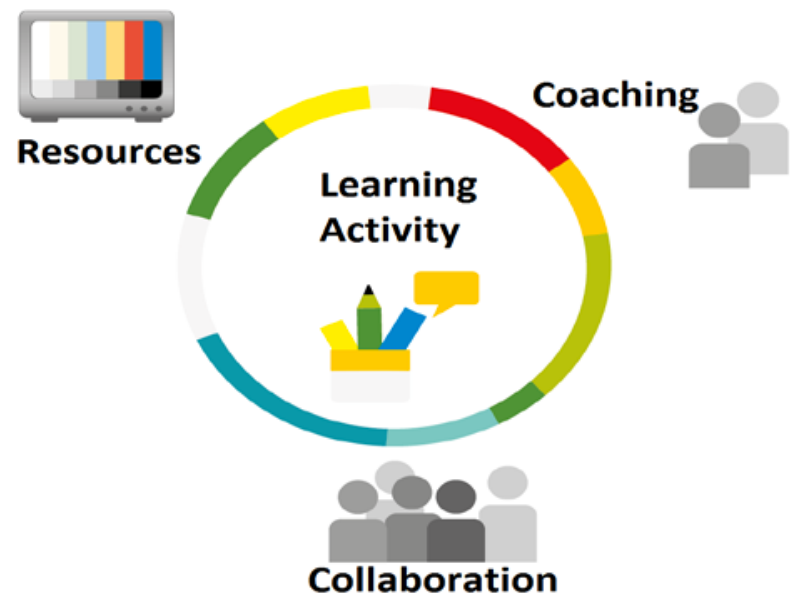

Figure 2. [10]. Basic elements based on educational model

According to the aforementioned, teachers may center the learning process on:

a. Contents \& Reproduction vs. Learning \& Understanding

According to [11], teachers who conceive learning as the appropriation of contents, usually promote in their students knowledge reproduction, while those who are focused on developing skills cultivate in their students phenomena understanding and meaning emphasis. It is noteworthy to say that learning contents are relevant in the learning process but this latter must be aimed at the student's skills development that enable him to use the acquired knowledge in diverse contexts for specific problem solving.

b. Complexity \& Transference

College teachers function seems to have been displaced lately from teaching to researching, an educator perspective that has some implications. On the one hand, the teacher must devote time to team research and, on the other hand, he must dedicate time for teaching. This double function, in many cases, does not have the needed recognition that would be required by the demand of assessing teachers' dedication times to different tasks and the implicit load it entails.

Subsequently, a college teacher load frequently leaves teaching as the task that is less time dedicated [9]. As a result, there is no time for reflecting on the pedagogical practice and the learning activities that work the best as students' learning process aids. Moreover, it must also be considered that college teachers are usually experts in their fields but need training because they have not received the pedagogical education that enables them to develop their teaching activities with all the needed reflection, appropriateness and pedagogical exchange implications.

Teaching in face-to-face and digital environments is not far from these changes experienced in college. In addition, institutions must face the need to train teachers to successfully develop their teaching practice; there lays the crucial role of the exchange possibilities offered by the teacher to students for having a real learning building process, no matter the education mode. Among other issues to have in mind, surfing opportunities and data search must be implicit in the students' learning process.

Moreover, the new social and environmental demands require the students' learning to be focused on understanding phenomena and to be able to solve identified problems supported by various disciplines. These new requirements need new didactic approaches by the teacher where autonomous learning is encouraged, as well as setting in motion the mechanisms and abilities for identifying difficulties and proposing solutions for them. These new teaching and learning methods require using active methodologies as problem based learning, project learning or case studies in which the skills for building and using knowledge are truly developed.

Learning for understanding naturally implies learning activities that facilitate understanding problems, identifying needs and appropriating the conditions that surround any phenomenon or difficulty; in that way, for 
the teacher to be able to guide students on this understanding path, the following conditions should exist, as [12] claim:

1. A global idea on content: a meaningful structure for relating data.

2. Prior active knowledge for interpreting data.

Tasks proposed by the teacher must help to activate relevant previous knowledge for the student to relate it with new information and thus achieve the true meaning of learning. This understanding of information by the student is evidenced in the explanations given by him in his own words of the related data he has learned.

Accordingly, the teacher must present new situations in order to know the level of meaning appropriation by the student and, subsequently, he must favor the link between new and previous knowledge through a hierarchical structure. This new way of teaching and learning requires greater effort from the teacher for proposing students activities in which they use new knowledge for understanding a phenomenon and/or propose solution alternatives for any given problem.

This innovative teacher task must be accompanied by information on his students' prior capabilities and knowledge that enables him to identify what is their level of understanding and, if needed, redirect the activities so as to reach all the students' understanding. In order to achieve the students' focus on knowledge understanding, leaving behind knowledge repetition, [12] suggest the following strategies:

1. Avoid questions and tasks that enable reproductive answers: Guide the students to infer from presented data, to relate data, and to confront the solution of new cases and situations where they have to use the new knowledge.

2. Allow and favor resources use (books, notes, data access, etc.): Let students use knowledge through information and communication technologies.

3. Design an on-going evaluation system: Start with an evaluation of students' previous knowledge, propose several evaluations along the term in order to assess learning evolution, and allow evaluations to be, by themselves, a learning opportunity for students.

4. Value pupils' own ideas: Allow students to paraphrase, describe and build their own responses, plus favor self-evaluation and hetero-evaluation of learned knowledge.

5. Use open tasks that admit more than one-way solution possibility: Offer students problems close to their professional reality to foster the use of knowledge in contexts similar to those they will face.

Facilitating the relationship between previous and new knowledge could be a difficult task for the teacher because it should be focused towards linking knowledge, reorganizing prior knowledge and/or establishing new connections with the acquired knowledge (conceptual change). It requires a trifold process of explaining, restructuring and re-describing. A problem-solving proposal is a strategy that enables the teacher to build a true significant learning of students, where the teacher must clearly differentiate between task and problem. For a task to be a real problem, it must fulfill three requisites: it has to be open; it should not have strict rules for reaching a solution, so the student should be able to make decisions along the process; and, it must be totally student-centered.

\section{Developing the Computing Education Competence}

Acknowledging the teacher's duty in the student's knowledge building implies exploring new mechanisms for teachers' training and student-centered learning structure. It is from this perspective that Universidad de La Sabana (located in Bogotá, Colombia), is concerned about the quality improvement processes of higher education, and has designed and developed strategies that allow an affluent students' education from diverse angles [13]. One of the University's front lines for reaching the quality and efficiency goals is the Technologies for the Academy Center; it is an academic and service unit that encourages the ICT's integration to the academy with a humanistic and innovative sense in its teaching, researching and social work processes.

Its main object of study is computing education, defined by [14] as an inter-discipline that studies the computing - education relationship, as well as the practical and theoretical generated transformations produced by their synergy.

Teaching \& learning processes developed in the Center seek to change learning activities into part of the core process of complete training, aimed at encouraging personal growth processes framed into the group culture of the student. The Center looks for the diverse sciences curricula contents and the very same activity of concept apprehension that constitute the vehicle for comprehensively educating the student, in such a way that encourages him the certainty that he is the lead actor of his own education process [13].

The Center teachers are members of the Technologies for the Academy Group PROVENTUS, a research group accredited at the National Science and Technology System of Colombia (COLCIENCIAS, in Spanish), whose main goal is to support the country's necessities by developing research and innovation projects that identify, assess and increase the ICT's impact on education [15].

The Technologies for the Academy Group PROVENTUS has elaborated, as part of its research processes, the computing education competence guidelines for the teachers of Universidad de La Sabana. The development of these guidelines is included in the current plan of the Technologies for the Academy Center and it is part of the following design:

Strategic objective: Strengthening teaching \& learning processes by integrating ICT's.

Strategy: Consolidating a permanent computing education path for graduate and postgraduate teachers of the University.

Actions:

- Diagnosis of the computing education competence level of teachers.

- Development of a computing education path for graduate and postgraduate teachers.

- Introduction of computing education competences as teachers entry requirement to the teachers ranking.

- Introduction of ICT's related products as part of teachers production assessment.

- Design ofa LONGITUDINAL research project for continuous monitoring of teachers education path. 
- Development of a management system for the teachers education path and for monitoring computing education competences.

In order to reach the goal and action plans abovementioned, the research group members designed guidelines for developing the computing education competence which, in the first place, attends to the recommendations of internationally recognized agencies such as [16] in its document "ICT Competence Standards for Teachers", and the Colombian Ministry of National Education in its document “Appropriateness of ICT's in the teaching professional development”[17].

Secondly, results of the group research activity are taken into account as it could be traced to works such as: “ICT's Inventory” [18], “ICT's Integration Cases to Higher Education" [15], and "Data Management Competences in Higher Education Students" [19] - all of them changed into valuable referents for guidelines' building.

According to UNESCO, each country must encourage:

- Students and teachers ICT's access.

- Quality digital educational contents.

- Teachers' skills' development so their students will develop competences in using ICT's.

Hence, it recommends including three approaches that must be considered when pondering an educational reform: basic ICT's notions, deepening knowledge and generating knowledge; all of them should be interconnected with educational system issues such as curriculum, educational policy, pedagogy, ICT's use, organization, and teachers' training. When crossing approaches and issues a standards matrix was generated as world-class reference for teachers to develop the required competences that enabled them to develop the demanded competences in order to improve the teaching and learning process.

Regarding the Colombian Ministry of National Education, there are two levels of cognitive appropriateness:

1. Personal appropriateness level: where teachers understand the opportunities and challenges represented by using ICT's for their personal productivity regarding diverse educational contexts, and where they are able to exchange with other teachers by using and sharing varied communication tools.

2. Professional or in-depth appropriation level: where they are set more ambitious goals that have a direct impact on the teaching practice, hence they hopefully positively affect students and their education. The goals sketched out in the document for this latter level are:

- Appropriating ICT's with a pedagogical spirit, beyond the instrumental management, for developing students' competences.

- Producing new strategies that modify teaching practices.

- Reflecting and assuming a critical position on ICT's incorporation processes in academic environments as well as on the existing resources associated.

- Updating and strengthening the discipline knowledge by using ICT's.

- Contributing to knowledge transfer and transformation processes of the classroom and/or the institution.
At this level, a crucial aim consists on designing and implementing actions that allow developing students' competences; that is to say, that it is not only the teachers' development, but as previously explained, supporting the competences development of third parties.

Regarding the investigations' results, some of the most relevant contributions are next presented in order to build the proposal:

In their research, “ICT's Inventory”, [18] identified and classified the ICT's uses made by college teachers for educational purposes, and a comparative reference framework is set for diverse authors to classify ICT's integration tools with teaching and learning processes. Some other authors propose ICT's integration levels departing from familiarization, passing through teaching support, re-orientation towards students' learning, until an evolved level associated with social knowledge building. Finally, a key conclusion showed that the great majority of these teachers use ICT's as a teaching support. Others study [20] propose a model for ICT integration for come back to teachers to implementing sophisticated instructional systems that require more specific computer skills for improve a interaction of teacher to student and student to student for example. This model include pedagogical levels based in factors how: teacher pedagogical beliefs, instructional strategies used, teacher student interactions and the types of tasks students are expected to carry out.

In “ICT's Integration Cases to Higher Education" [15], a multiple case study was conducted in which 17 learning environments were analyzed in order to present the way for integrating ICT's with integration results regarding learning. Likewise, it was identified that most of the teachers considered that students learn more and better when using hardware and software. However, one of the cases evidenced that such apremise is not real because it was observed that ICT excess in a learning environment does not develop, nor improve the learning process.

Finally, it was considered that the in progress computing education teaching plan, designed and executed by the Technologies for the Academy Center, was responding to the challenges proposed by the Institutional Educational Project, regarding the complete education of teachers. This plan was conceived on two stages: a basic stage and an in-depth stage.

Once all the mentioned elements are considered, with its intention primarily for the educational community of Universidad de La Sabana, computing education competence must be understood as those actions that are verifiable through different evidences, and that are capable of assessing their own ICT's appropriation processes in the academic environments where they take place.

It is important mentioning that it is not intended to cover a complete and direct appropriation of the abovementioned academic proposals but those that are required for the University's academic community; that is to say, those that,-given our teachers' requirements- will be subject of development in order to significantly contribute to the Institutional Educational Project (PEI in Spanish), to the Educational Projects of the Program (PEP in Spanish), and to teachers' careers.

Standards and indicators of the computing educational competence of Universidad de La Sabana teachers are presented in the following table: 


\begin{tabular}{|c|c|c|}
\hline \multicolumn{3}{|c|}{ IE Teacher strengthens teaching \& learning processes by innovatively integrating ICT’s } \\
\hline Standard & Indicator & Examples \\
\hline \multirow{5}{*}{$\begin{array}{l}\text { 1.Teacher basically uses } \\
\text { computing tools \& } \\
\text { identifies, access, assesses \& } \\
\text { applies data in his academic } \\
\text { activities } \\
\text { (10 points) }\end{array}$} & $\begin{array}{l}\text { 1.1 Teacher uses ICT's for personal activities } \\
\text { (4 points) }\end{array}$ & $\begin{array}{l}\text { Takes his students \& his own notes } \\
\text { Designs an academic program } \\
\text { Handles attendance lists } \\
\text { Handles email } \\
\text { Participates inWeb conferences } \\
\text { Takes virtual courses }\end{array}$ \\
\hline & $\begin{array}{l}\text { 1.2 Teacher identifies information needs } \\
\text { (1 point) }\end{array}$ & $\begin{array}{l}\text { Poses questions \& identifies enquiries } \\
\text { Writes an information search plan } \\
\text { Analyzes the required information for solving a given problem }\end{array}$ \\
\hline & $\begin{array}{l}\text { 1.3 Teacher accesses information efficiently } \\
\text { (1 point) }\end{array}$ & $\begin{array}{l}\text { Identifies \& locates sources of adequate \& reliable data (Evidence } \\
\text { accumulation process for supporting inferences from found data). } \\
\text { (Internet Use, online dictionaries, digital libraries, data bases, } \\
\text { specialized web portal) }\end{array}$ \\
\hline & $\begin{array}{l}\text { 1.4 Teacher relates \& applies criteria for assessing data \& } \\
\text { its sources } \\
\text { ( } 2 \text { points) }\end{array}$ & $\begin{array}{l}\text { Assesses data quality } \\
\text { Classifies \& organize data } \\
\text { Analyzes data } \\
\text { Summarizes data } \\
\text { Contrasts data }\end{array}$ \\
\hline & $\begin{array}{l}1.5 \text { Teacher applies prior \& new data for planning \& } \\
\text { creating any particular product or activity } \\
\text { ( } 2 \text { points) }\end{array}$ & $\begin{array}{l}\text { Applies data in different contexts } \\
\text { Uses \& communicates learned knowledge } \\
\text { Creates a product with found data }\end{array}$ \\
\hline \multirow{5}{*}{$\begin{array}{l}\text { 2.Teacher integrates ICT's } \\
\text { for improving the quality of } \\
\text { the teaching process in } \\
\text { learning environments( } 20 \\
\text { points) }\end{array}$} & $\begin{array}{l}2.1 \text { Teacher designs } \& \text { uses educational digital resources for } \\
\text { the teaching process } \\
\text { ( } 4 \text { points) }\end{array}$ & $\begin{array}{l}\text { Tutorials } \\
\text { Electronic presentations } \\
\text { Readings } \\
\text { Data, charts } \\
\text { Graphs } \\
\text { Animations } \\
\text { Training documents } \\
\text { Web pages } \\
\text { Educational software } \\
\text { Multimedia resources }\end{array}$ \\
\hline & $\begin{array}{l}\text { 2.2Teacher uses ICT's for designing assessment activities } \\
\text { for his students } \\
\text { ( } 4 \text { points) }\end{array}$ & $\begin{array}{l}\text { Quizzes } \\
\text { Mid-term exams } \\
\text { Questionnaires } \\
\text { Workshops } \\
\text { Assignments } \\
\text { Forums } \\
\text { Webquests } \\
\text { Criteria design for assessing evaluation activities }\end{array}$ \\
\hline & $\begin{array}{l}2.3 \text { Teacher develops evaluation \& feedback strategies using } \\
\text { ICT's } \\
\text { ( } 4 \text { points) }\end{array}$ & $\begin{array}{l}\text { Co-evaluation supported by ICT’s } \\
\text { Electronic portfolios } \\
\text { Evaluations re-design } \\
\text { Diverse digital \& electronic media for evaluation \& feedback }\end{array}$ \\
\hline & $\begin{array}{l}\text { 2.4 Teacher supports his teaching practice with Virtual } \\
\text { Sabana or similar platforms } \\
\text { (4 points) }\end{array}$ & $\begin{array}{l}\text { Course academic program } \\
\text { Bibliography } \\
\text { Documents } \\
\text { Presentations } \\
\text { Resources linked to other websites }\end{array}$ \\
\hline & $\begin{array}{l}2.5 \text { Teacher participates in ICT-mediated academic } \\
\text { networks for supporting his teaching practice } \\
(4 \text { points })\end{array}$ & $\begin{array}{l}\text { Contacts experts and/or colleagues } \\
\text { Contributes to knowledge repositories } \\
\text { Is member of academic networks on specific topics }\end{array}$ \\
\hline \multirow{4}{*}{$\begin{array}{l}\text { 3. Teacher encourages his } \\
\text { students to use ICT's for } \\
\text { improving their learning } \\
\text { process } \\
\text { ( } 30 \text { points) }\end{array}$} & $\begin{array}{l}\text { 3.1Teacher proposes activities for his students manage } \\
\text { (identify, access, assess, evaluate \& apply) ICT-mediated } \\
\text { data } \\
\text { (5 points) }\end{array}$ & $\begin{array}{l}\text { Students' papers using ICT’s } \\
\text { In-class electronic presentations } \\
\text { Forums } \\
\text { Webquests } \\
\text { Scavenger hunts }\end{array}$ \\
\hline & $\begin{array}{l}\text { 3.2 Teacher designs \& uses digital educational resources for } \\
\text { improving his students' learning process } \\
\text { (5 points) }\end{array}$ & $\begin{array}{l}\text { Class guides } \\
\text { Tutorials } \\
\text { Workshops } \\
\text { Simulations } \\
\text { Webquests } \\
\end{array}$ \\
\hline & $\begin{array}{l}\text { 3.3 Teacher proposes activities to facilitate the student } \\
\text { independent work and students exchange through Virtual } \\
\text { Sabana or similar platforms } \\
\text { (10 points) }\end{array}$ & $\begin{array}{l}\text { Forums } \\
\text { Wikis } \\
\text { Blogs } \\
\text { Networks }\end{array}$ \\
\hline & $\begin{array}{l}\text { 3.4 Teacher proposes activities for students product design } \\
\text { \& development using ICT's } \\
\text { (10 points) }\end{array}$ & $\begin{array}{l}\text { Websites } \\
\text { Multimedia resources } \\
\text { Information systems } \\
\text { Videos } \\
\text { Podcasts }\end{array}$ \\
\hline \multirow{3}{*}{$\begin{array}{l}\text { 4-Teacher innovates his } \\
\text { pedagogical practice } \\
\text { supported by ICT's } \\
\text { ( } 30 \text { points) }\end{array}$} & $\begin{array}{l}\text { 4.1 Teacher plans \&systematize strategies for students to } \\
\text { design \& develop knowledge products by using ICT's } \\
\text { (10 points) }\end{array}$ & $\begin{array}{l}\text { Uses a computing tools in the reflection process } \\
\text { Performs learning activities for students }\end{array}$ \\
\hline & $\begin{array}{l}\text { 4.2 Teacher monitors his students when designing \& } \\
\text { developing ICT-mediated knowledge products } \\
\text { (10 points) }\end{array}$ & $\begin{array}{l}\text { Rubrics } \\
\text { Information systems for feedback } \\
\text { Monitoring templates } \\
\text { Field diaries } \\
\text { Digital portfolio }\end{array}$ \\
\hline & $\begin{array}{l}\text { 4.3 Teacher assesses strategies for students to design \& } \\
\text { develop ICT-mediated knowledge products } \\
\text { (10 points) }\end{array}$ & $\begin{array}{l}\text { As a result of pondering on his pedagogical practice, he introduces } \\
\text { changes on contents, evaluation material \& learning activities for his } \\
\text { students. } \\
\text { Integrates students through academic networks }\end{array}$ \\
\hline
\end{tabular}

Based on the guidelines, the group is currently identifying the development level of computing educational competence of Universidad de La Sabana teachers, by interviewing full time teachers in the first term of this year. These interviews will be personalized and they will work as a diagnostic tool. Simultaneously, the research project "Teaching education for developing the computing education competence in Higher 
Education" is being conducted in order to generate the teaching education path in computing education competence for teachers of Universidad de La Sabana so as to qualify their teaching practice.

Teachers' education involves an awareness teachers' campaign about the relevance of integrating ICT's pedagogically, whether in face-to-face or digital environments. This task is being worked out but there are still queries on how to approach the teachers' reflection on their teaching practice, on the best ways to approach teaching training and monitoring, key elements for adequately implement ICT's in the teaching practice.

\section{Conclusions}

-Teachers can develop several skills for integrate ICT in the curriculum, this training can help to find the best form for teach with technology [21].

-The teacher's training must concur thedevelopment of other competences suchas the methodological ones that, according to [3].

-The approaches about building knowledge in face-toface and digital teaching environments have their advantages and their drawbacks. These will be discussed taking into account the approaches of authors such as [6]. who claims that acquiring knowledge in these environments is affected by interaction processes, and highlighting the relevance of fostering communication among the agents of the interactive triangle teacherstudents-materials.

-Teachers' pedagogical thinking can play a role in integration ICT in the curriculum, teachers' who have a constructivist thinking can use ICT in the best way [7].

-Finally, a key conclusion showed that the great majority of these teachers use ICT's as a teaching support. Others study [20] propose a model for ICT integration for come back to teachers to implementing sophisticated instructional systems that require more specific computer skills for improve a interaction of teacher to student and student to student for example.

\section{References}

[1] Mishra, P \& Koehler, M. Technological pedagogical content knowledge: a framework for teacher knowledge. Teachers college record volume 108, number 6, 2006, 1017-1054.

[2] Prestidge, S. The beliefs behind the teacher that influence their ICT practices. Computers \& education 58, 2012, 449-458.

[3] Goodyear, P.; Salmon G.; Spector, M; Steeples, C \&Tickner, s. Competence for online teaching: a special report. educational technological. Research and development, 49(1), 2011, 65-72.
[4] UNESCO. Estándares de competencia en TIC para profesors.Electronic document available 2012 at: http://www.eduteka.org/pdfdir/unescoestandaresprofesors.pdf.

[5] Haydn, T. (2007). 'First do no harm': developing teachers' ability to use ict in subject teaching: some lessons from the UK.British Journal of Educational Technology.vol 38 no, 2007, 365-368.

[6] Sorathia, K \&Servidio, R. Learning and experience: teaching tangible interaction \& edutainment. international educational technology conference IETC. Social and behavioral sciences no 64, 2012, 265-274.

[7] Hammond, M. Reynolds, L. \& Ingram, J. How and why do student teachers use ict? centre for new technologies. Research in education, institute of education, university of warwick, coventry cv4 7al, ukblackwell publishing ltd journal of computer assisted learning, 27, 2011, 191-203.

[8] Guldberg, K., \& Pilkington, R. Tutor roles in facilitating reflection on practice through online discussion.Educationaltechnology\&society, 10 (1), 2007, 61-72.

[9] Martín, E. Profesorado competente para formar alumnado competente: el reto del cambio profesor en psicología del aprendizaje universitario: la formación en competencias. Editorial Morata, Madrid:, 2009.

[10] Gros, B. Evolución y retos de la educación virtual, construyendo el elearning del siglo XXI.Editorial UOC.Barcelona, 2011.

[11] Prosser; T. Understanding learning and teaching. the experience in higher education. Buckingham. The society for research into higher education \&open university press, 1999.

[12] Pozo, I.; Pérez, M. Psicología del aprendizaje universitario: la formación en competencias. Ediciones Morata, Madrid, 2009.

[13] Segovia, Y. La “departamentalización” del área de informática para la docencia. documento interno. Colombia: Universidad de La Sabana, 2004.

[14] Chiappe, A. \&Boude, O. El proyecto de maestría: algunos elementos importantes a considerar.in-housedocument of the master in computingeducation, universidad de la sabana. colombia: universidad de la sabana 2010.

[15] Jaramillo, P. \& Ruiz, M. Un caso de integración de tic que no agrega valor al aprendizaje. Revista latinoamericana de ciencias sociales, niños y juventud. Retrievedonmarch 10, 2010, at: http://www.umanizales.edu.co/revistacinde/index.html.

[16] Ministerio de educación nacional de colombia. Programa nacional de uso de medios y nuevas tecnologías. apropiación de tecnologías de la información y la comunicación -tic- en el desarrollo profesional docente. Retrieved on january 20 2010, at: http://wikiplanestic.uniandes.edu.co/lib/exe/fetch.php?media=visi on:ruta_superior.pdf.

[17] UNESCO. Formación docente y las tecnologías de la información y la comunicación. experiencias de formación docente utilizando tecnologías de información y comunicación. Retrieved on January 20 2010, at: http://unesdoc.unesco.org/images/0014/001410/141010s.pdf.

[18] Jaramillo, P., Castañeda, P. \& Pimienta, M. Inventario de usos de las tic para aprender y enseñar. informe final del proyecto integración de tic en educación superior, fase 1. Colombia: Universidad de La Sabana, 2008.

[19] Jaramillo, P; Hennig, C; Rincón, Y ¿Cómo manejan información los estudiantes de educación superior? el caso de la universidad de la sabana, Colombia.información, cultura y sociedad. 2011, 117-143.

[20] Mein, J; Wang, P \& Chun, I. Pedagogy * technology: a twodimensional model for teachers'.

[21] UNESCO. ICT competency framework for teachers. Paris. 2011. 